\title{
BIOAVAILABILITY OF AMOXICILLIN IN CHICKENS
}

\author{
EL BARAWY, A. M. ${ }^{1}$, S. A.YOUSSEF ${ }^{2}$ AND M. M. ISMAEL ${ }^{2}$ \\ 1 Animal Health Research Institute, ARC, Ministry of Agriculture , Dokki ,Giza \\ 2 Faculty of Veterinary Medicine, Cairo University.
}

(Manuscript received 30 March 2011)

\begin{abstract}
For evaluation of bioavailability of amoxicillin in chickens during prophylactic treatment by salinomycin ( $60 \mathrm{ppm}$ ), 66 one day old chicks were divided into 2 groups, non-treated one $\left(G_{1}\right)$ and treated group $\left(G_{2}\right)$. Serum concentrations of amoxicillin after single intravenous, oral and intramuscular doses ( $15 \mathrm{mg} / \mathrm{kg}$ b.wt. ) were determined. Multiple oral doses (same dose twice daily for 5 consecutive days) were also given for tissue residue studies. Non-compartmental calculations of pharmacokinetic parameters after single intravenous dosing revealed that half-life of distribution ( $t 0.5 \mathrm{a}$ ) was $0.19 \pm 0.05 \mathrm{~h}$ and $0.14 \pm 0.03 \mathrm{~h}$, while, halflife of elimination ( $\mathrm{t} 0.5 \beta$ ) was $2.57 \pm 0.07 \mathrm{~h}$ and $2.06 \pm 0.08 \mathrm{~h}$ in $\mathrm{G}_{1}$ and $\mathrm{G}_{2}$, respectively. Central volumes of distribution of amoxicillin $\left(\mathrm{V}_{\mathrm{c}}\right)$ were $0.20 \pm 0.03$ and $0.19 \pm 0.04 \mathrm{~L} / \mathrm{kg}$, respectively. Area under curve $\left(\right.$ AUC $_{\mathrm{IV}}$ ) was $95.74 \pm 4.22 \mathrm{mg} . \mathrm{h} / \mathrm{L}$ in $\mathrm{G}_{1}$ and significantly decreased to 74.76 $\pm 3.24 \mathrm{mg} . \mathrm{h} / \mathrm{L}$ in $\mathrm{G}_{2}$, respectively . Mean residence times (MRT) were $3.35 \pm 0.73$ and $2.67 \pm 0.81$ hours in $\mathrm{G}_{1}$ and $\mathrm{G}_{2}$, respectively. After single oral dose maximum concentration ( $\mathrm{C}_{\max }$ ), maximum time ( $\mathrm{T}_{\max }$ ), MRT and bioavailability ( $\mathrm{F} \%$ ) were $0.99 \pm 0.06$ and $0.89 \pm 0.08 \mu \mathrm{g} / \mathrm{ml}, 3.25 \pm$ 0.35 and $3.48 \pm 0.14$ hours , $8.19 \pm 1.08$ and $7.48 \pm 0.85$ hours , $20.41 \pm$ 2.05 and $23.87 \pm 1.51 \%$ in $\mathrm{G}_{1}$ and $\mathrm{G}_{2}$, respectively . After single intramuscular dose $\mathrm{C}_{\max }, \mathrm{T}_{\text {max }}, \mathrm{MRT}$ and $\mathrm{F} \%$ were $0.89 \pm 0.14,0.85 \pm$ $0.13 \mu \mathrm{g} / \mathrm{ml} 1.85 \pm 0.24$ and $1.88 \pm 0.15 \mathrm{~h}, 7.23 \pm 1.88$ and $6.21 \pm 2.13 \mathrm{~h}$, $12.28 \pm 1.82 \mathrm{~h}$ and $13.42 \pm 2.21 \%$ in $\mathrm{G}_{1}$ and $\mathrm{G}_{2}$, respectively . Prophylactic dose of salinomycin slightly improved bioavailability of amoxicillin in chickens.
\end{abstract}

\section{INTRODUCTION}

Amoxicillin ( $\alpha$-amino-p-hydroxybenzyl penicillin) is a medium-spectrum $\beta$-lactam antibacterial agent ( semi-synthetic penicillin) widely used in veterinary medicine. It is the drug of choice because of its better absorption within its class. On the other hand, coccidiosis possesses an ever present threat to any intensive rearing process, specially with low hygienic measures in developing countries. Salinomycin is a polyether ionophore usually used as a growth promoter and coccidiostat (Meliton, 2007) . It is a forming lipid soluble, dynamically reversible complexes with cations and by this means, facilitates specific ionic transport across biological membranes (Meliton, 2007). Its narrow safety margin is a major cause of concern with regarding to its oxidative stress on both liver and kidney. Association between longer treatment courses and maximal bacterial eradication rates, gives it to be an alternative composite target taking into consideration duration of therapy, serum concentration 
and MIC (Pichichero et. al., 2008). The mean minimum inhibitory concentration (MIC) of amoxicillin for Salmonella spp. is $0.8 \mu \mathrm{g} / \mathrm{ml}$, for Escherichia coli $6.25 \mu \mathrm{g} / \mathrm{ml}$, for Streptococcus pyogenes $0.015 \mu \mathrm{g} / \mathrm{ml}$ and Streptococcus pneumoniae $<0.012$ $\mu \mathrm{g} / \mathrm{ml}$ (Cruick Shank et. al., 1975). Research tools should assess the factors affecting drug absorption. Emerging threats from increased drug resistance and the possibility of increased microbial virulence enforce judicious use of antimicrobial agents to achieve the best long term approach and proper treatment guidelines.

The present work was conducted to study influences of prophylactic treatment with salinomycin on bioavailability of amoxicillin which may help in the design of proper and effective dosing regimens in broiler farms.

\section{MATERIALS AND METHODS}

Sixty six-one day old Hubbard broiler chicks were obtained from Elwady Poultry Company . The birds were fed on balanced ration (free from antibiotics) and allowed to drink water ad - libitum.

Amoxicillin trihydrate is a water soluble semi-synthetic penicillin . The drug was obtained as a pure powder from the Laboratory Research of Pfizer Pharmaceutical Co., Animal Health Division, Cairo .

Salinomycin sodium premix (coxistac) was obtained from Pfizer Pharmaceutical Co. , Animal Health Division, Cairo. Each kilogram contains 60 grams of salinomycin. The premix was thoroughly and horizontally mixed with regular ration to give final concentration of $60 \mathrm{ppm}$ of salinomycin in feed .

\section{Microbiological assay of amoxicillin}

Culture media : The antibiotic medium No. 1 was supplied by EL -Nasr Pharmaceutical and Chemical Company . It was used for assay of amoxicillin . The $\mathrm{PH}$ of the prepared medium was adjusted to $8.0 \pm 0.1$.

Test organism:Salinomycin resistant Sarcinea lutea(ATCC 9341a ) was obtained from Department of Bacteriology, Animal Health Research Institute, Dokki. Cairo.

\section{Preparation of salinomycin resistant Sarcinea lutea suspensions}

The test organism was maintained on agar slant containing $10 \mathrm{ml}$ of nutrient agar incubated at $32-35^{\circ} \mathrm{C}$ for 24 hours. The growth was harvested with $3 \mathrm{ml}$ of sterile saline from the agar surface. The suspension of organism was spread over the entire surface in Raux bottle containing $300 \mathrm{ml}$ of antibiotic medium No.1 and incubated at $32-35^{\circ} \mathrm{C}$ for 24 hours. The resulting growth was collected from the agar surface by washing with $50 \mathrm{ml}$ of sterile saline. Sarcinea lutea (ATCC 9341a) was adopted for presence of salinomycin by several passages of Sarcinea 
Iutea in the gradually increased low levels of salinomycin starting with $2 \mu \mathrm{g} / \mathrm{ml}$ which is less than recorded MIC ( $8 \mu \mathrm{g} / \mathrm{ml}$ by Tanaka et. al., 1974 ). Salinomycin was dissolved in methanol in 10 concentrations $(100 \mu \mathrm{g}-1 \mathrm{mg} / \mathrm{ml})$. Filter paper disks were soaked in $20 \mu \mathrm{l}$ from each dilution till complete absorption and left to complete dryness, then, immediately used for gradual adaptation process. Sarcinea lutea was finally sensitive to $<0.01 \mu \mathrm{g} / \mathrm{ml}$ amoxicillin and resistant to $>10 \mu \mathrm{g} / \mathrm{ml}$ salinomycin . It was used for assay of all samples including the standard curve. The obtained suspensions were diluted with sterile saline to give a density of $10^{6}$ cell / $\mathrm{ml}$ Brown's opacity tubes ( 7 of 10 tubes) of barium sulphate standard ( Cruick Shank et al ., 1975). The suspension was standardized by dilution with sterile saline to give $25 \%$ light transmission calorimetrically at a wave length $580 \mathrm{~nm}$ using $13 \mathrm{~mm}$ diameter of test tube absorption cell . All utensils and dishes were sterilized before using in hot air oven.

\section{Preparation of culture media according to Cruick Shank et al . ,1975}

For each $100 \mathrm{ml}$ of autoclaved and warm (about $37^{\circ} \mathrm{C}$ ) agar medium adjusted to $\mathrm{pH} 8,0.5 \mathrm{ml}$ of microorganism spore suspension was added for assay of amoxicillin .The medium was mixed well to obtain homogenous suspension . Twentyfive $\mathrm{ml}$ of the prepared medium were poured into each Petri dish (20 x120 mm) using sterile cylinder with $25 \mathrm{ml}$ capacity which had been previously sterilized. The plates were left at room temperature on complete horizontal surface till complete solidification. Two to six pores (according to the drug concentration) were made on the surface of agar using sterilized stainless steel pore maker with an outside diameter of $8 \mathrm{~mm}( \pm 0.1)$ and inside diameter of $6 \mathrm{~mm}( \pm 0.1)$ (Cruick Shank et al . , 1975).

\section{Preparation of phosphate buffer solution}

Phosphate buffer $0.1 \mathrm{M}$ ( $\mathrm{pH}=6 \pm 0.05$ ) was prepared as described by Lashev and Drumev (1983) as follows:

$\begin{array}{lcc}\text { Dibasic potassium phosphate } & 2.0 \mathrm{~g} \\ \text { Monobasic potassium phosphate } & 8.0 \mathrm{~g} \\ \text { Sterilized distilled water up to } & 1000.0 \mathrm{ml}\end{array}$

\section{Preparation of standard solutions of amoxicillin}

The standard solution of amoxicillin was prepared by dissolving $1000 \mu \mathrm{g}$ in $10 \mathrm{ml}$ distilled water to obtain a concentration of $100 \mu \mathrm{g} / \mathrm{ml}$. Working standard concentrations were made by further dilutions in $0.1 \mathrm{M}$ phosphate buffer to obtain concentrations of $0.060,0.125,0.250,0.500$ (reference concentrations), 1.000, 
$2.000,4.000,8.000$ and $16.000 \mu \mathrm{g} / \mathrm{ml}$ for preparing of standard curve (Arret et. al. , 1971).

\section{Preparation of standard curves}

According to Cruick Shank et. al . , (1975), three plates were used for each concentration except the reference concentration which was used in all plates. Six pores were made in each plate, three of which were inoculated with tested concentration, while, the other three pores were inoculated with reference concentration. The plates were incubated at $37^{\circ} \mathrm{C}$ for $24-36$ hours. The diameter of the inhibition zones was then measured by triplicate manner. Average reading of the tested concentration and the reference concentration were calculated. The increase in values of the average reference in set of three plates than the whole reference determinations was added to the average determination of the tested concentration. The decrease in values of average reference determination in set of three plates than the average of the whole reference determinations was subtracted from the average determination of the tested concentration. The corrected values included the average of the whole reference. Concentrations were plotted on semi-logarithmic paper using concentrations in $\mu \mathrm{g} / \mathrm{ml}$ as ordinate and the diameter of the zone of inhibition $(\mathrm{mm})$ as abscissa. The standard curves were then constructed .

\section{Assay of samples}

According to Arret et al . (1971), three plates were used for each sample, six pores were made, three of which were filled with reference concentration, and the other three pores were filled with serum samples in an alternating manner. The plates were incubated at $37^{\circ} \mathrm{C}$ for $24-36$ hours. The average diameters of inhibition zones of samples were corrected by using the zone of diameter of the reference concentration as mentioned previously in the preparation of the standard curves . From the standard curve, the concentrations corresponding to the corrected values of the zone diameter were obtained .

\section{Grouping of chickens}

Sixty-six chickens were divided into two groups of thirty three chickens each. The chickens in the 1st group (G1) were non-treated and fed balanced ration free from antibiotics. The 2 nd group (G2) was fed balanced ration (free from antibiotics) and supplemented with $60 \mathrm{ppm}$ salinomycin sodium ( coxistac ). The pharmacokinetic aspects of Amoxicillin were studied either in $\mathrm{G} 1$ or G2. Amoxicillin trihydrate was administered either as a single dose intravenously on 28th day of life to 18 chicks from each group then, intramuscularly or orally (intracrop by stomach tube) on 43rd day of life to 9 chicks from each group. Multiple oral doses were given 
to another 15 chicks from each group on $43^{\text {rd }}$ day of life. All chicks had free access to ration and water ad libitum .

\section{Single dose study}

All salinomycin treated groups (G2) were examined for assurance of the salinomycin concentration in serum being completely tolerated by the test microorganism, and no inhibition zones were produced. Amoxicillin was injected (in left wing vein ) at a dose of $15 \mathrm{mg} / \mathrm{Kg}$ body weight (18 birds from each group) . Blood samples ( about $1 \mathrm{ml}$ each ) were collected from the right wing vein at different time intervals of $5,1015,30$ minutes $, 1,2,4,6,8,12$ and 24 hours after intravenous administration for determination of serum concentrations of tested antibacterial agent using microbiological assay method. Chickens were then, left for 2 weeks to ensure that the drugs were completely excreted from their bodies, then, half of chickens ( 9 birds from each group) was administered the drug orally with the same dose, while, the other half of 9 birds from each group was injected with the same dose of the drug intramuscularly. Blood samples were collected at different time intervals of 15,30 minutes and $1,2,4,6,8,12$ and 24 hours following drug administration for determination of amoxicillin concentrationas as described by Baggot (1978).

\section{Multiple oral dose, tissue distribution and residue studies}

All salinomycin treated groups (G2) were examined for assurance of the salinomycin concentration in serum being completely tolerated by the test microorganism and no inhibition zones were produced as described by Arret et al. (1971) . Amoxicillin was given orally to 15 chickens from each group at a dose of $15 \mathrm{mg} / \mathrm{Kg}$ b.wt. twice daily, for 5 consecutive days. After the last dose, 3 chickens from each group were slaughtered at $2,24,48,72$ and 96 for studying of amoxicillin residues. Serum and tissue samples of liver, kidney, lung , brain , breast muscles, thigh muscles, spleen and heart were taken for determination of antibiotic residues.

\section{Pharmacokinetic analysis}

A pharmacokinetic computer program (R Strip, Micromath, Utah, USA) was used following intravenous dose, and suggested the use of the following biexponential equation: $\mathrm{Ct}=\mathrm{Ae}-\mathrm{at}+\mathrm{Be}-\beta \mathrm{t}$ (Baggot, 1978) where $\mathrm{Ct}$ is the serum concentration of amoxicillin, $t$ is the time after intravenous administration, $A$ and $a$ are the intercept and slope, respectively of the distribution phase, $B$ and $\beta$ are the intercept and slope of the elimination phase, e is the base of the natural logarithm. Equations could be summarized as following: 
$\operatorname{Ln2}(0.693)$

$$
\begin{gathered}
\mathbf{t}_{0.5 \alpha} \text { or } \mathbf{t}_{0.5 \beta}=\quad-\quad \alpha \text { or } \beta
\end{gathered}
$$

Where :

$$
\begin{aligned}
& \text { Ln2 = Natural logarithm . } \\
& \alpha=\text { distribution rate constant } \text {. } \\
& \beta=\text { Elimination rate constant } \\
& \text { Dose }(\mu \mathrm{g} / \mathrm{Kg})
\end{aligned}
$$

Mean residence time $=A U M C / A U C$

AUC of oral or intramuscular

Bioavailability $\%=$

AUC intravenous

\section{Statistical analysis}

The results of pharmacokinetic parameters ( Mean \pm S.E) were statistically analyzed by using Student's $t$ test as explained by Petrie and Watson (2006) and using SPSS 15 computer program. The difference was considered significant when $P$ $<0.05,<0.01$ or $<0.001$

\section{RESULTS AND DISCUSSION}

Following single intravenous, oral and intramuscular doses (figures 1,2 and3), it appeared that, salinomycin treated chickens (G2) have slightly lower amoxicillin serum concentration than non-treated ones (G1). Zero time $\left(\mathrm{C}^{\circ}\right)$ drug concentration intercepts( Table 1) was 75.84 7.44 in $\mathrm{G} 1$ and $78.38 \pm 6.65 \mu \mathrm{g} / \mathrm{ml}$ in $\mathrm{G} 2$. Hybrid rate constants of biphasic intravenous disposition (a) were higher in G2 (4.88 \pm $\left.0.85 \mathrm{~h}^{-1}\right)$ and $\left(3.74 \pm 0.64 \mathrm{~h}^{-1}\right)$ in $\mathrm{G1}$, respectively, while, $(\beta)$ was lower in G1 $\left(0.27 \pm 0.04 h^{-1}\right)$ than $G 2\left(0.34 \pm 0.05 h^{-1}\right)$. Distribution half-lives $\left(t_{0.5}\right.$ a $)$ were reported in G1 $(0.19 \pm 0.05$ h. ) and in G2 $(0.14 \pm 0.03 \mathrm{~h}$. ), while, elimination halflives $\left(t_{0.5 \beta}\right)$ were $2.57 \pm 0.7$ hours in $G 1$ and $2.06 \pm 0.8 \mathrm{~h}$. in $\mathrm{G} 2$. Area under the curve $\quad\left(A_{U} C_{I V}\right)$ was significantly higher in $\mathrm{G} 1(95.74 \pm 4.22 \mathrm{mg} \cdot \mathrm{h} / \mathrm{L})$ than in $\mathrm{G} 2$ $(74.76 \pm 3.24 \mathrm{mg} . \mathrm{h} / \mathrm{L})$, while, volume of distribution by extrapolation method $\left(\mathrm{V}_{\mathrm{dc}}\right)$ was lower in $\mathrm{G} 2(0.19 \pm 0.04 \mathrm{~L} / \mathrm{kg})$ than $\mathrm{G} 1(0.20 \pm 0.03 \mathrm{~L} / \mathrm{kg})$. Total body clearance $\left(\mathrm{Cl}_{\mathrm{t}}\right.$ ) was $0.16 \pm 0.05 \mathrm{~L} / \mathrm{kg} / \mathrm{h}$ in $\mathrm{G} 1$ and $0.21 \pm 0.03 \mathrm{~L} / \mathrm{kg} / \mathrm{h}$ in $\mathrm{G} 2$. Volume 
of distribution( $\mathrm{Vd}_{\mathrm{c}}$ ) was convenient to that recorded by Abo El Sooud et al. ( 2004) $(0.23 \pm 0.01 \mathrm{~L} / \mathrm{kg})$ in chickens.

After single oral dose (Table 2), the maximum concentration (Cmax) was higher in $\mathrm{G} 1(0.99 \pm 0.06 \mu \mathrm{g} / \mathrm{ml})$ than in $\mathrm{G} 2(0.89 \pm 0.08 \mu \mathrm{g} / \mathrm{ml})$. The half-life of absorption ( t $0.5 \mathrm{a}$ ) was lower in $\mathrm{G} 1(1.04 \pm 0.12 \mathrm{~h})$ as compared with $\mathrm{G} 2(1.23 \pm 0.25 \mathrm{~h})$, while, elimination half-life ( t $0.5 \beta$ )was $(5.75 \pm 0.05 \mathrm{~h}$ ) in $\mathrm{G} 2$ and significantly higher in $\mathrm{G} 1(6.38 \pm 0.15 \mathrm{~h}$ ) in G1. Area under curve ( AUC oral ) was lower in G2 $(17.84 \pm 2.16 \mathrm{mg} . \mathrm{h} / \mathrm{L})$ than in $\mathrm{G} 1(19.54 \pm 1.37 \mathrm{mg} . \mathrm{h} / \mathrm{L})$. Mean resident time ( MRT) was lower in G2 $(7.48 \pm 0.85 \mathrm{~h})$ than $\mathrm{G} 1(8.19 \pm 1.08 \mathrm{~h})$.Area under moment curve ( AUMC oral ) was significantly lower in G2 $(80.63 \pm 5.33 \mathrm{mg} . \mathrm{h} 2$ / L ) than $\mathrm{G} 1(160.00 \pm 3.25 \mathrm{mg} . \mathrm{h} 2 / \mathrm{L})$. The elimination half-life $(\mathrm{t} 0.5 \beta$ ) after intravenous injection was nearly 2 times lower than that after oral administration. The results indicated that amoxicillin was distributed quickly after oral dosing. The elimination was greatly influenced by the route of administration. In G2 amoxicillin administered orally was rapidly but incompletely absorbed from the gastrointestinal tract . Changes in pharmacokinetics of amoxicillin trihydrate after oral administration to albino rats may be due to experimental impairment of kidney and liver. Miller and Wyatt , ( 1985 ) recorded similar suggestions to chlortetracycline in aflatoxicated chickens.

Following administration of single intramuscular dose of amoxicillin ( $15 \mathrm{mg} / \mathrm{kg}$ b.wt. ) in G1and G2,the maximum concentration ( $\mathrm{C}$ max ) in serum( Table 3) was lower in $\mathrm{G} 2(0.85 \pm 0.13 \mu \mathrm{g} / \mathrm{ml})$ than in $\mathrm{G} 1(0.89 \pm 0.14 \mu \mathrm{g} / \mathrm{ml})$ and at maximum times (Tmax) $(1.88 \pm 0.15 \mathrm{~h})$ in $\mathrm{G} 2$ and $(1.85 \pm 0.24 \mathrm{~h})$ in G1. Absorption rate

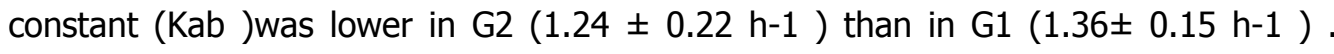
Absorption half-life (t $0.5 \mathrm{ab})$ was lower in $\mathrm{G} 1(0.51 \pm 0.03 \mathrm{~h})$ than in G2 $(0.56 \pm$ $0.15 \mathrm{~h}$ ) . Elimination half-life was $4.18 \pm 0.35 \mathrm{~h}$ in $\mathrm{G} 2$ and and higher in $\mathrm{G} 1$ (4.86 \pm $0.21 \mathrm{~h}$ ). Area under the curve ( AUCIM ) was shorter in G2 (10.03 $\pm 1.34 \mathrm{mg} . \mathrm{h} / \mathrm{L})$ than in non-treated $(11.76 \pm 2.11 \mathrm{mg} \cdot \mathrm{h} / \mathrm{L})$. Mean resident time (MRT) was lower in G2 $(6.21 \pm 2.13 \mathrm{~h})$ than $\mathrm{G} 1(7.23 \pm 1.88 \mathrm{~h})$. Area under moment curve ( AUMC i.m ) was significantly lower in G2 $(62.33 \pm 7.56 \mathrm{mg} . \mathrm{h} 2 / \mathrm{L})$ than in $\mathrm{G} 1(84.99 \pm 5.41 \mathrm{mg}$ . h2 / L ). The MRT was nearly similar in both oral and intramuscular routs, since therapeutically, effective blood levels are achieved after intramuscular injection, and plasma concentration higher than $2 \mu \mathrm{g} / \mathrm{ml}$ is maintained for about 7 hours as a dose interval of 8 hours will thus produce plasma concentration greater than MIC for numerous pathogens. Pennington et. al. ( 1975 ) suggested the need of frequent estimation of the drug concentrations in serum during fever . Baggot (1978) established that effective concentration of the drug being achieved and maintained at the site of infection influenced by physiological conditions . 
The oral bioavailability was $20.41 \pm 2.05 \%$ in G1 and $23.87 \pm 1.51 \%$ in G2 which was lower than that reported in chickens ( $60.92 \%$ ) by Abo El Sooud et al. , (2004) and (63\%) by Anadon et. al. (1996) . It was near to that recorded in pigeons ( $20 \%$ ) by Dorrestein et. al. (1986). The variation may be due anatomy and digestive physiology in birds (Carceles et. al., 1995). The intramuscular bioavailability determined in this study $(12.28 \pm 1.82 \%$ in G1 and $13.42 \pm 2.21 \%$ in G2 ) was lower than that observed in chickens ( $77.21 \%$ ) by Abo El Sooud et al. ( 2004) and for pigeons ( $57 \%$ ) by Dorrestein et al.( 1986). Amoxicillin is not stable in an acidic medium at $37{ }^{\circ} \mathrm{C}$ or in higher temperatures as reported by Zhepeng Liu et al. (2005).

The values obtained following multiple oral doses of amoxicillin $(15 \mathrm{mg} / \mathrm{kg}$ b.wt. twice daily for 5 consecutive days ) in serum and tissues (Table 4) showed that the drug was widely distributed allover selected tissues and organs ( liver , kidney, lung , brain , breast, thigh , spleen and heart ) with decrease in drug concentration in serum after multiple oral doses in G2. The drug was within detectable limits in all organs ( except spleen and heart ) for 48 hours and still detected in kidney till 72 hours. Concentrations in kidney were respectively 1.5 to 2 times the corresponding serum concentrations . Similar findings were reported by Lashev and Drumev (1983) in ducks. Clinically, relevant susceptibility breakpoints should be developed for virtually all relevant antimicrobial agents used to treat infectious diseases, based on pharmacokinetic and pharmacodynamic parameters. We conclude that prophylactic dose of salinomycin slightly improved bioavailability of amoxicillin in chicken .

Table 1. Pharmacokinetic parameters of amoxicillin insalinomycin non-treated (G1) and treated chickens(G2) After a single intravenous dose of $15 \mathrm{mg} / \mathrm{kg}(\mathrm{n}=9)$.

\begin{tabular}{|c|c|c|c|}
\hline Parameter & Unit & Non-treated(G1) & Treated(G2) \\
\hline $\mathbf{C}^{\mathbf{0}}$ & $\mu \mathrm{g} / \mathrm{ml}$ & $75.84 \pm 7.44$ & $78.38 \pm 6.65$ \\
\hline $\boldsymbol{\alpha}$ & $\mathrm{h}^{-1}$ & $3.74 \pm 0.64$ & $4.88 \pm 0.85$ \\
\hline $\mathbf{t}_{\mathbf{0 . 5} \boldsymbol{\alpha}}$ & $\mathrm{h}$ & $0.19 \pm 0.05$ & $0.14 \pm 0.03$ \\
\hline $\boldsymbol{\beta}$ & $\mathrm{h}^{-1}$ & $0.27 \pm 0.04$ & $0.34 \pm 0.05$ \\
\hline $\mathbf{t}_{\mathbf{0 . 5} \boldsymbol{\beta}}$ & $\mathrm{h}$ & $2.57 \pm 0.7$ & $2.06 \pm 0.8$ \\
\hline $\mathbf{V}_{\mathbf{c}}$ & $\mathrm{L} / \mathrm{kg}$ & $0.20 \pm 0.03$ & $0.19 \pm 0.04$ \\
\hline $\mathbf{V d}_{\mathbf{s s}}$ & $\mathrm{L} / \mathrm{kg}$ & $0.49 \pm 0.08$ & $0.50 \pm 0.06$ \\
\hline $\mathbf{V d}_{\text {area }}$ & $\mathrm{L} / \mathrm{kg}$ & $0.57 \pm 0.06$ & $0.59 \pm 0.05$ \\
\hline $\mathbf{C l}_{\mathbf{t}}$ & $\mathrm{L} / \mathrm{h} / \mathrm{kg}$ & $0.16 \pm 0.05$ & $0.21 \pm 0.03$ \\
\hline AUC $_{\mathbf{~} \mathbf{v}}$ & $\mathrm{mg} \cdot \mathrm{h} / \mathrm{L}$ & $95.74 \pm 4.22$ & $74.76 \pm 3.24 * *$ \\
\hline AUMC $_{\mathbf{~} \mathbf{v}}$ & $\mathrm{mg} \cdot \mathrm{h}^{2} / \mathrm{L}$ & $320.26 \pm 12.66$ & $199.94 \pm 14.35 * * *$ \\
\hline MRT & $\mathrm{h}$ & $3.35 \pm 0.73$ & $2.67 \pm 0.81$ \\
\hline
\end{tabular}

$* * \mathrm{P}<0.01$

$* * * \mathrm{P}<0.001$ 
Table 2. Pharmacokinetic parameters of amoxicillin in salinomycin non-treated (G1)and treated chickens (G2) after a single oral dose of 15 $\mathrm{mg} / \mathrm{kg}$ b. wt. $(\mathrm{n}=9)$.

\begin{tabular}{|c|c|c|c|}
\hline Parameter & Unit & Non-treated (G1) & Treated (G2) \\
\hline $\mathbf{K}_{\mathrm{ab}}$ & $h^{-1}$ & $0.67 \pm 0.08$ & $0.56 \pm 0.04$ \\
\hline$t_{0.5} a b$ & $\mathrm{~h}$ & $1.04 \pm 0.12$ & $1.23 \pm 0.25$ \\
\hline $\mathbf{K}_{\mathrm{el}}$ & $h^{-1}$ & $0.11 \pm 0.05$ & $0.12 \pm 0.03$ \\
\hline$t_{0.5} \mathrm{el}$ & $\mathrm{h}$ & $6.38 \pm 0.15$ & $5.75 \pm 0.05^{* *}$ \\
\hline$C_{\max }$ & $\mu \mathrm{g} / \mathrm{ml}$ & $0.99 \pm 0.06$ & $0.89 \pm 0.08$ \\
\hline $\mathbf{T}_{\max }$ & $\mathrm{h}$ & $3.25 \pm 0.35$ & $3.48 \pm 0.14$ \\
\hline MRT & $\mathrm{h}$ & $8.19 \pm 1.08$ & $7.48 \pm 0.85$ \\
\hline MAT & $\mathrm{h}$ & $4.84 \pm 0.81$ & $4.82 \pm 0.53$ \\
\hline AUC $_{\text {oral }}$ & Mg.h/L & $19.54 \pm 1.37$ & $17.84 \pm 2.16$ \\
\hline AUMC $_{\text {oral }}$ & $M g \cdot h^{2} / L$ & $160.00 \pm 3.25$ & $80.63 \pm 5.33 * * *$ \\
\hline $\mathbf{F}$ & $\%$ & $20.41 \pm 2.05$ & $23.87 \pm 1.51$ \\
\hline
\end{tabular}

$* * \mathrm{P}<0.01$

$* * * \mathrm{P}<0.001$

Table 3. Pharmacokinetic parameters of amoxicillin in salinomycin non-treated (G1) and treated chickens (G2) after a single i.m dose of $15 \mathrm{mg} / \mathrm{kg}$ b. wt. $(n=9)$.

\begin{tabular}{|c|c|c|c|}
\hline Parameter & Unit & Non-treated(G1) & treated(G2) \\
\hline $\mathbf{K}_{\mathrm{ab}}$ & $h^{-1}$ & $1.36 \pm 0.15$ & $1.24 \pm 0.22$ \\
\hline$t_{0.5 a b}$ & $\mathrm{~h}$ & $0.51 \pm 0.03$ & $0.56 \pm 0.15$ \\
\hline$K_{\text {el }}$ & $\mathrm{h}^{-1}$ & $0.14 \pm 0.07$ & $0.16 \pm 0.03$ \\
\hline $\mathbf{t}_{0.5 \mathrm{el}}$ & $\mathrm{h}$ & $4.86 \pm 0.21$ & $4.18 \pm 0.35$ \\
\hline$C_{\max }$ & $\mu \mathrm{g} / \mathrm{ml}$ & $0.89 \pm 0.14$ & $0.85 \pm 0.13$ \\
\hline$T_{\max }$ & $\mathrm{h}$ & $1.85 \pm 0.24$ & $1.88 \pm 0.15$ \\
\hline MRT & $\mathrm{h}$ & $7.23 \pm 1.88$ & $6.21 \pm 2.13$ \\
\hline MAT & $\mathrm{h}$ & $3.88 \pm 0.62$ & $3.53 \pm 0.81$ \\
\hline $\mathrm{AUC}_{\mathrm{i} . \mathrm{m}}$ & Mg.h/L & $11.76 \pm 2.11$ & $10.03 \pm 1.34$ \\
\hline AUMC $_{\mathrm{i} . \mathrm{m}}$ & $M g \cdot h^{2} / L$ & $84.99 \pm 5.41$ & $62.33 \pm 7.56^{* * *}$ \\
\hline $\mathbf{F}$ & $\%$ & $12.28 \pm 1.82$ & $13.42 \pm 2.21$ \\
\hline
\end{tabular}


Table 4. Tissue concentrations of amoxicillin $(\mu \mathrm{g} / \mathrm{gm})$ in salinomycin non-treated (G1) and treated chickens (G2) following multiple oral doses of 15 $\mathrm{mg} / \mathrm{kg} \mathrm{b}$. wt. twice daily for 5 days $(n=3)$.

\begin{tabular}{|c|c|c|c|c|c|}
\hline \multirow{2}{*}{ organ } & \multicolumn{5}{|c|}{ Time of slaughter } \\
\hline & & $2 \mathrm{~h}$ & $24 \mathrm{~h}$ & $48 \mathrm{~h}$ & $72 \mathrm{~h}$ \\
\hline \multirow[t]{2}{*}{ Serum } & (G1) & $2.067 \pm 0.07$ & $0.77 \pm 0.05$ & $0.41 \pm 0.08$ & ND \\
\hline & (G2) & $1.75 \pm 0.03$ & $0.623 \pm 0.02$ & $0.287 \pm 0.02$ & ND \\
\hline \multirow{2}{*}{ Liver } & (G1) & $1.78 \pm 0.06$ & $0.68 \pm 0.08$ & $0.32 \pm 0.03$ & ND \\
\hline & (G2) & $1.23 \pm 0.15^{*}$ & $0.58 \pm 0.05$ & $0.30 \pm 0.03$ & ND \\
\hline \multirow{2}{*}{ Kidney } & (G1) & $4.20 \pm 0.21$ & $2.84 \pm 0.26$ & $1.75 \pm 0.05$ & $0.95 \pm 0.04$ \\
\hline & (G2) & $3.85 \pm 0.16$ & $2.76 \pm 0.21$ & $1.44 \pm 0.05^{*}$ & $0.77 \pm 0.06$ \\
\hline \multirow{2}{*}{ Lung } & (G1) & $1.28 \pm 0.06$ & $0.80 \pm 0.04$ & $0.42 \pm 0.02$ & ND \\
\hline & (G2) & $1.12 \pm 0.06$ & $0.75 \pm 0.03$ & $0.37 \pm 0.02$ & ND \\
\hline \multirow{2}{*}{ Brain } & (G1) & $0.83 \pm 0.02$ & $0.50 \pm 0.02$ & $0.25 \pm 0.03$ & ND \\
\hline & (G2) & $0.72 \pm 0.02^{*}$ & $0.47 \pm 0.02$ & $0.23 \pm 0.01$ & ND \\
\hline \multirow{2}{*}{ Breast } & (G1) & $1.26 \pm 0.07$ & $0.80 \pm 0.10$ & $0.54 \pm 0.05$ & ND \\
\hline & (G2) & $1.09 \pm 0.05$ & $0.76 \pm 0.06$ & $0.49 \pm 0.04$ & ND \\
\hline \multirow{2}{*}{ Thigh } & (G1) & $1.23 \pm 0.06$ & $0.69 \pm 0.09$ & $0.42 \pm 0.05$ & ND \\
\hline & (G2) & $1.14 \pm 0.02$ & $0.61 \pm 0.09$ & $0.36 \pm 0.03$ & ND \\
\hline \multirow{2}{*}{ spleen } & (G1) & $0.62 \pm 0.06$ & $0.52 \pm 0.03$ & ND & ND \\
\hline & (G2) & $0.62 \pm 0.04$ & $0.33 \pm 0.03^{*}$ & ND & ND \\
\hline \multirow{2}{*}{ Heart } & (G1) & $0.85 \pm 0.03$ & $0.42 \pm 0.02$ & ND & ND \\
\hline & (G2) & $0.81 \pm 0.02$ & $0.45 \pm 0.03$ & ND & ND \\
\hline
\end{tabular}

$* \mathrm{P}<0.05$

$\mathrm{ND}=$ Not detected

Table 5. Average of feed consumed per bird in G1\&G2.

\begin{tabular}{|c|c|c|}
\hline \multirow{2}{*}{ Weeks } & Non-treated(G1) & Treated(G2) \\
\cline { 2 - 3 } & Feed consumed (gm) & Feed consumed (gm) \\
\hline $\mathbf{1}$ & 130 & 110 \\
\hline $\mathbf{2}$ & 184 & 168 \\
\hline $\mathbf{3}$ & 225 & 211 \\
\hline $\mathbf{4}$ & 490 & 456 \\
\hline $\mathbf{5}$ & 560 & 538 \\
\hline $\mathbf{6}$ & 589 & 568 \\
\hline Total & 2178 & 2051 \\
\hline
\end{tabular}


Fig. 1. 
Fig. 2. 
Fig. 3. 


\section{REFERENCES}

1. Abo El-Sooud K., Y. H., Al-Tarazi and M. M., Al-Bataineh. 2004. Comparative pharmacokinetics and bioavailability of amoxycillin in chickens after intravenous , intramuscular and oral administration . Vet. Res. Communications. 28: 599 607.

2. Anadon A., M. R., Martinez,Larranaga , M. J. Diaz, P. Bringas, M. C. Fernandez, M.A. Martinez and M.L. Fernandez Cruz. 1996 . Pharmacokinetics of amoxycillin in broiler chickens Avian Path. , 25 (3): $449-458$.

3. Arret B., D. P. Johnson and A. Kirshbaum. 1971. Outline of details for microbiological assays of antibiotics. J. Pharm. Sci. , $60: 1690-1694$.

4. Baggot J. D. 1978. Some aspects of clinical pharmacokinetics in Veterinary Medicine II . J. Vet. Pharm. Therap. , 1:111 - 118.

5. Carceles C.M., M. Soledad Vicente and E.Escudero. 1995.Pharmacokinetics of amoxycillin - clavulanic acid combination after intravenous and intramuscular administration to turkeys and chickens .Avian Pathol. , 24 (4) :643 - 652.

6. Cruick Shank R., J. P. Duguid, B. P. Marmion and R. H. Swain. 1975. Medical Microbiology 12 th Ed. , 2 NewYork.

7. Dorrestein G. M., J. D. Rinzema and M.N. Buitelaar. 1986. Tissue distribution of amoxycillin after oral and intramuscular administration of pigeon(Columba Livia ) .Avian Path., 15 (4): $663-676$.

8. Lashev L. and D. Drumev. 1983. Blood concentrations of amoxycillin in farm animals and poultry injected intramuscularly with the sodium and trihydrate salts. Veterinarnomeditsinski Nauki , 20, $9: 96-105$

9. Meliton N. N. 2007. Ionophores . Veterinary Toxicology Basic and Clinical Principles , Chapter 83 : 1021-1041.

10. Miller B. L. and R. D. Wyatt. 1985. Effect of dietary aflatoxin on the uptake and elimination of chlorotetracycline in broiler chicks .Poult. Sci., 64:1637 -43.

11. Pennington J. E. , C. D. Dale, H. Y. Reynolds and J. D. Maclory. 1975. Gentamicin sulphate pharmacokinetics : lower levels of gentamicin in blood during fever. J. Inf. Dis., 132(3) : $270-275$.

12. Petrie,A. and P. Watson. 2006. Statistics for Veterinary and Animal Science .1st Ed., pp90-99 , The blachwell Science Ltd,UK. 
13. Pichichero, M., J. Casey, S. Block, R. Guttendorf , H. Flanner, D. Markowitz and S. Clausen. 2008. Pharmacodynamic analysis and clinical trial of Amoxicillin Sprinkle QD for 7 Days Compared to Penicillin VK QID for 10 days in the treatment of tonsillopharyngitis due to Streptococcus Pyogenes in Children. Antimicrobial Agents and Chemotherapy, 52, (7): 2512-2520.

14. Tanaka Yoshiaki, Saito Hideo, Miyazaki Yukio, Sugawara Hideo, Junsaku Nagatsu and Mitsuo Shibuya. 1974. US Patent (19) . Appl.No 410,030.

15. Zhepeng L., L. Weiyue, Q. Lisheng, Z. Xuhui, Z. Pengyun and P. Jun. 2005. In vitro and in vivo studies on mucoadhesive microspheres of amoxicillin. J. Contro. Release, 102( 1): 135-144. 


\title{
الإتاحة الحيوية للأموكسيسيللين في الاجاج
}

\author{
عبد العظيم البراوي1 1 ، صلاح عبد الحميد² ، محمد اسماعيل2 \\ 1 معه بحوث صحة الحيوان - مركز البحوث النزراعية - وزارة الزراعة - الدقي - الجيزة \\ 2 كلية الطب البيطري - جامعة القاهرة
}

استهدفت هذه الدر اسه تقييم الإتاحة الحيويه للأموكسيسيللين في الدجاج المغذى على عليقة تحتوي على السالينوميسين (بتركيز 60 جزء فى المليون) ـ تم تقسيم 66 كتكوت الى مجموعتبن متساويتين ، المجموعة الأولى (مجموعة ضلابطة مغذاه على عليقة خالية من السالينوميسين)

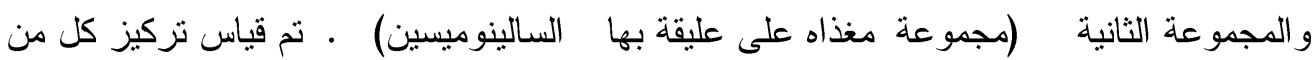
الأموكسيسيللين فى المصل و الأنسجه بطريقة الفحص الميكروبيولوجى وتم أيضاً حساب معدل إستفادة أجسام الدجاج (الإتاحة الحيويه) بعد إعطاء جرعه واحده ( 15 مجم /كجم من الوزن بالحقن الوريدي

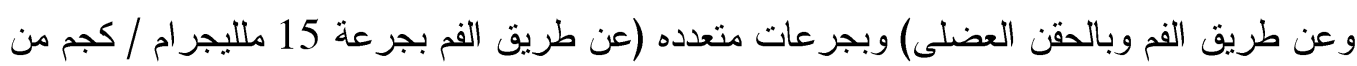

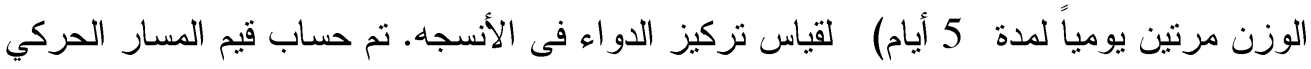

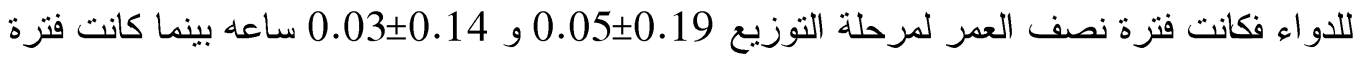

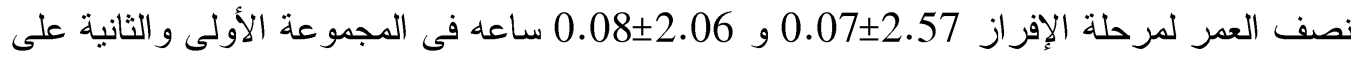

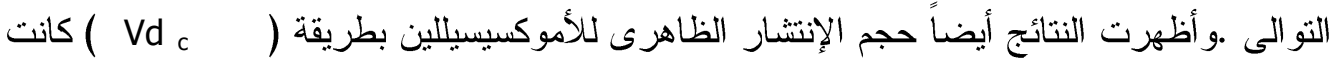

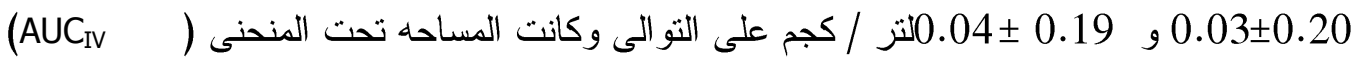

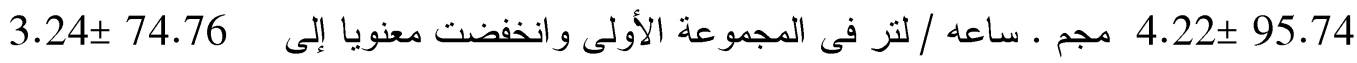

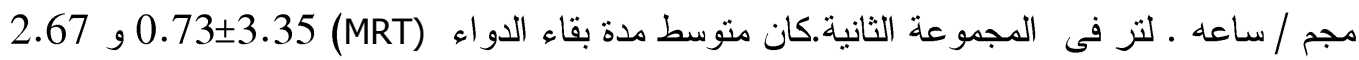

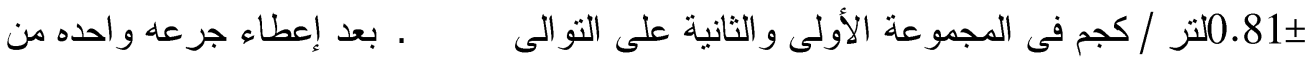

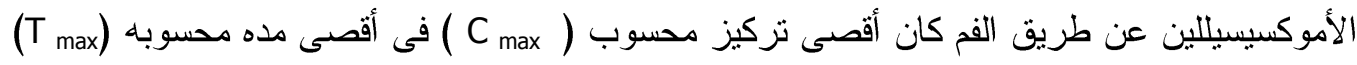

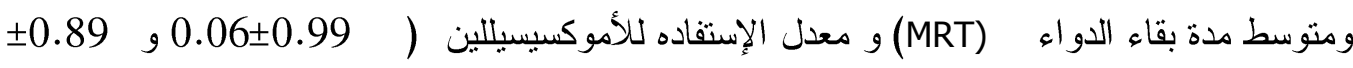

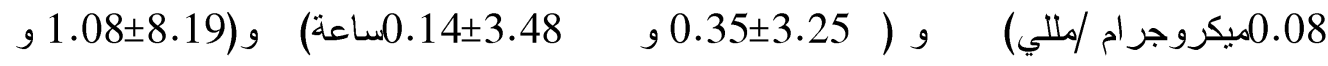

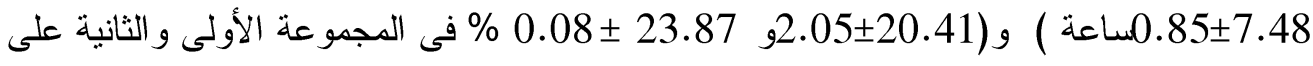

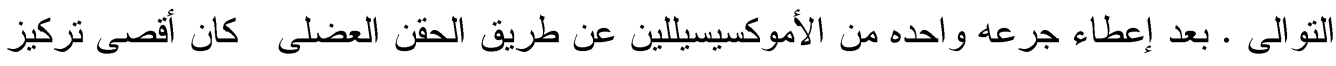

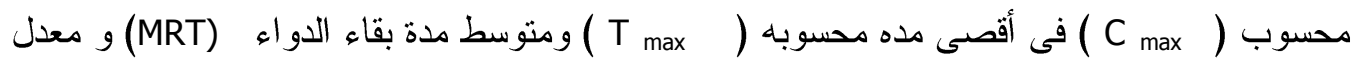

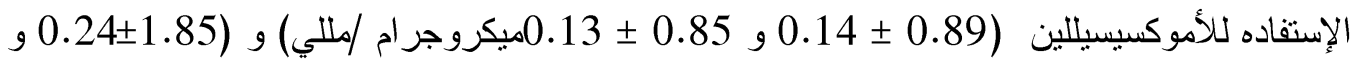

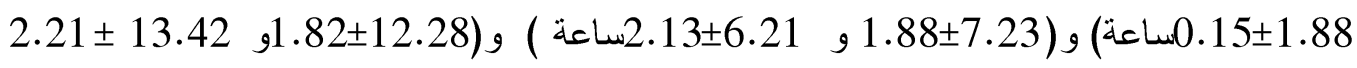
\% فى المجموعة الأولى و الثانية على التوالى .الوصي الدراسة باستخدام الجرعه الوقائيه من

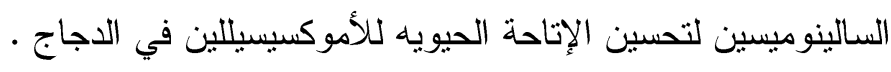

